\title{
Pelatihan dan Penyuluhan Usaha Otak-Otak Ikan di Perumahan Dinas PT KAI Kota Surabaya
}

Titus Kristanto $^{1}$, Ika Ratniarsih ${ }^{2}$, Dian Pramita Eka Laksmiyanti ${ }^{3}$, Sukarnaen ${ }^{4}$, Yunita Ardianti Sabtalistia ${ }^{5}$

Program Studi Rekayasa Perangkat Lunak, Institut Teknologi Telkom Surabaya ${ }^{1}$

Jl. Gayungan PTT No.17-19 Surabaya

tintus.chrisegmail. com ${ }^{1}$

Program Studi Arsitektur, Institut Teknologi Adhi Tama Surabaya ${ }^{2,3,4}$

Jl. Arief Rachman Hakim No.100 Surabaya

dianpra8@gmail. $\mathrm{com}^{3}$

Program Studi Arsitektur, Universitas Tarumanagara ${ }^{5}$

Jl. Letjen S. Parman No.1 Jakarta

Abstract

Tujuan dari kegiatan pengabdian masyarakat adalah memberikan keterampilan kepada masyarakat dalam hal berwirausaha otak-otak ikan, mengurangi jumlah pengangguran dan menambah etos kerja dalam melaksanakan aktivitas. Metode kegiatan yang digunakan adalah pelatihan, penyuluhan, pendampingan, dan praktik langsung pembuatan otak-otak ikan. Lokasi kegiatan berada di perumahan dinas PT KAI Kota Surabaya. Hasil dari kegiatan pengabdian masyarakat adalah meningkatkan pengetahuan dan keterampilan masyarakat dalam pembuatan dan memasarkan produk otak-otak ikan.

Kata Kunci - pelatihan, penyuluhan, pendampingan, otak-otak ikan

\section{PENDAhuluan}

Perumahan dinas PT KAI merupakan rumah dinas milik PT KAI, yang dikelola langsung PT KAI. Lokasi rumah dinas PT KAI berada di daerah Pacarkeling Kota Surabaya. Perumahan dibangun dalam rangka untuk memenuhi kebutuhan tempat tinggal bagi pegawai PT KAI.

Sampai saat ini perumahan dinas PT KAI bukan lagi dihuni oleh pegawai PT KAI, tetapi sudah dihuni masyarakat umum. Mayoritas penduduk yang tinggal di perumahan dinas adalah pensiunan PT KAI dan pedagang keliling. Salah satunya pedagang otak-otak ikan yang bernama Bapak Agus. Lokasi berjualan Bapak Agus di sekitar Pasar Pacarkeling Surabaya. Bapak Agus berjualan mulai pagi sampai sore. Bapak Agus merupakan Mitra 1 dari kegiatan pengabdian masyarakat.

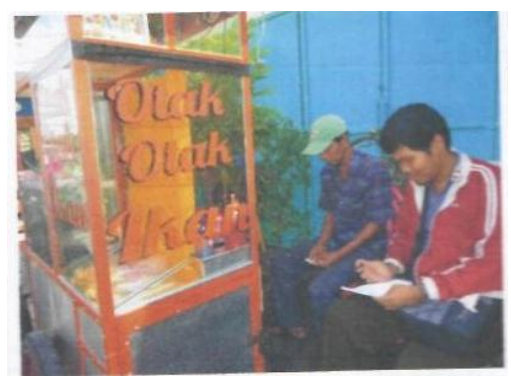

Gambar 1. Survey ke Mitra 1 (Bapak Agus)
Selain Bapak Agus, ada juga teman dari Bapak Agus yang jualan otak-otak ikan. Teman Bapak Agus bernama Bapak Anton. Lokasi jualan Bapak Anton berada di sekitar Galaxy Mall Surabaya. Setiap hari Bapak Anton jualan otak-otak ikan mulai siang sampai sore hari. Bapak Anton merupakan Mitra 2 dari kegiatan pengabdian masyarakat.

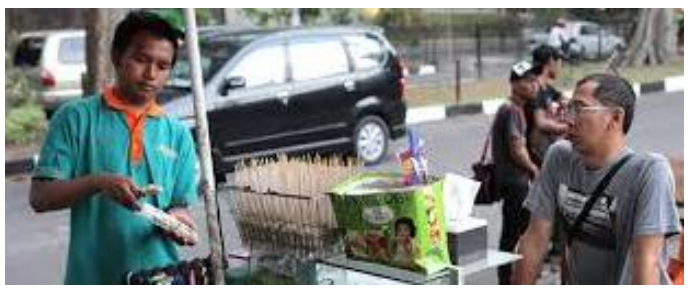

Gambar 2. Survey ke Mitra 2 (Bapak Anton)

Berdasarkan dari hasil survey lapangan yang dilakukan ke Mitra 1 dan Mitra 2, didapatkan hasil dari survey lapangan yaitu :

- Cara berjualan Mitra yaitu berupa di dorong keliling.

- Peralatan yang digunakan oleh Mitra masih sederhana berupa kompor, wajan, dan sebagainya.

- Pendapatan kotor dari Mitra 1 tiap bulan sekitar Rp450.000 sampai Rp750.000. Sedangkan pendapatan kotor dari Mitra 2 tiap bulan sekitar Rp550.000 sampai Rp850.000.

Bahan baku yang digunakan Mitra dalam membuat otakotak ikan adalah ikan tenggiri yang sudah dihaluskan, 
bawang putih, bawang merah, tepung terigu, santan kelapa kental gula pasir, baking powder, merica, garam, dan minyak goreng secukupnya. Jika tidak ada ikan tenggiri bisa diganti dengan ikan bandeng, ikan kakap, atau ikan selera anda. Bahan baku otak-otak ikan dapat dilihat pada Gambar 3.

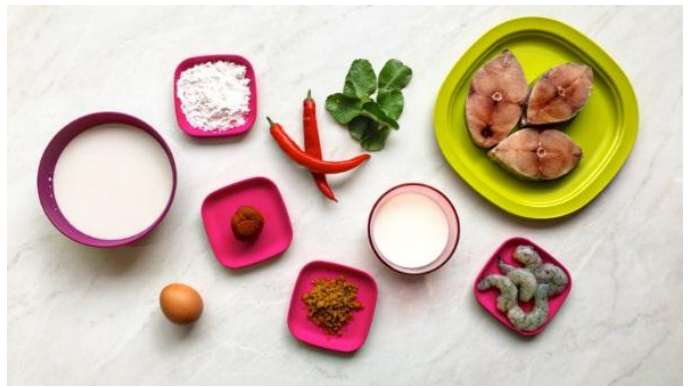

Gambar 3. Bahan baku otak-otak ikan

Sedangkan peralatan yang digunakan Mitra dalam memasak otak-otak ikan yaitu pisau, telenan, waskom plastik, kompor, alat penumbuk, wajan, dan LPG $3 \mathrm{~kg}$. Peralatan memasak otak-otak ikan dapat dlihat pada Gambar 4.

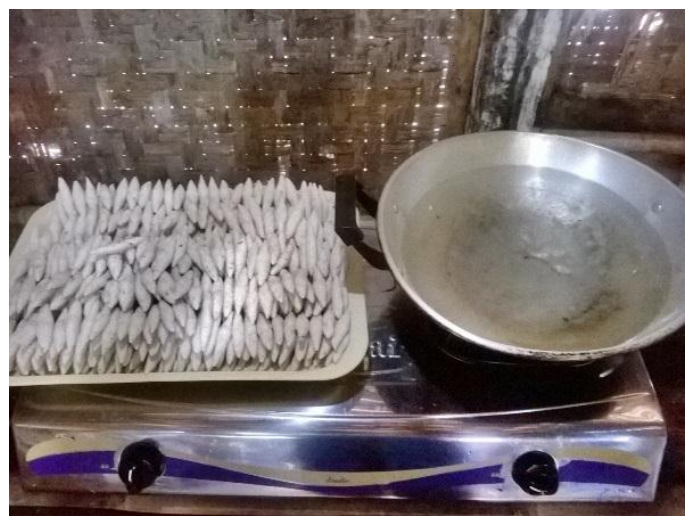

Gambar 4. Peralatan memasak otak-otak ikan

Tabel 1 menunjukkan spesifikasi dan kuantitas peralatan yang digunakan oleh Mitra PKM.

TABEL 1

SPESIFIKASI PERALATAN MITRA

\begin{tabular}{|c|l|c|c|}
\hline No & \multicolumn{1}{|c|}{$\begin{array}{c}\text { Jenis } \\
\text { Peralatan }\end{array}$} & Jumlah & Keterangan \\
\hline \multicolumn{3}{|l|}{ Mitra 1 (Bapak Agus) } \\
\hline 1 & Kompor & 1 & Baik \\
\hline 2 & Wajan & 1 & Baik \\
\hline 3 & LPG 3 kg & 2 & Baik \\
\hline 4 & $\begin{array}{l}\text { Perkakas dan } \\
\text { alat } \\
\text { pemotong : } \\
\text { waskom, } \\
\text { pisau, telenan }\end{array}$ & Beberapa & Baik \\
\hline \multicolumn{3}{|l}{ Mitra 2 } \\
\hline
\end{tabular}

\begin{tabular}{|c|l|c|c|}
\hline 1 & Wajan & 2 & Baik \\
\hline 2 & LPG 3 kg & 2 & Baik \\
\hline 3 & Kompor & 1 & Baik \\
\hline 4 & $\begin{array}{l}\text { Perkakas dan } \\
\text { alat } \\
\text { pemotong : } \\
\text { waskom } \\
\text { pisau, telenan }\end{array}$ & Beberapa & Baik \\
\hline
\end{tabular}

Berikut proses pelanggan membeli otak-otak ikan yaitu :

- Pelanggan atau pembeli datang ke mitra untuk membeli otak-otak ikan

- Mitra membuat dan memasak otak-otak ikan ke dalam kompor dan wajan. Proses pembuatan sekitar 5-10 menit.

- Customer setia untuk menunggu hingga otak-otak ikan matang.

- Setelah 5-10 menit berselang, otak-otak ikan matang, ditiriskan terlebih dahulu, lalu dibungkuskan ke customer

- Otak-otak ikan siap untuk disantap

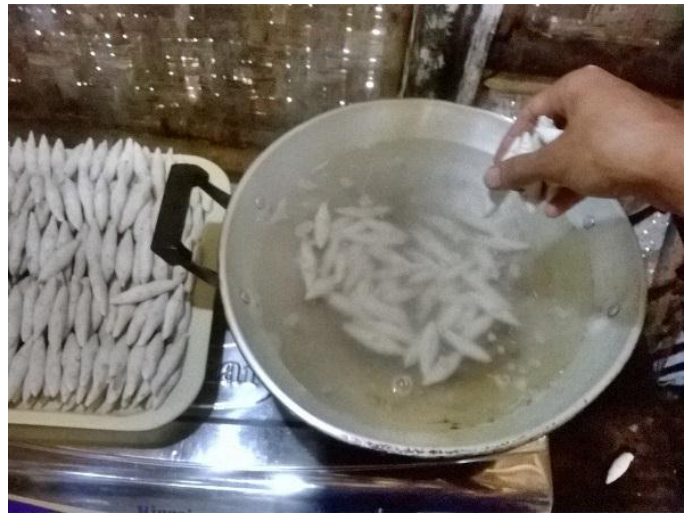

Gambar 5. Cara memasak otak-otak ikan

\section{A. Permasalahan Mitra}

Berdasarkan permasalahan yang terjadi pada Mitra, maka terbagi menjadi beberapa aspek yaitu aspek produksi, produk, dan pemasaran (Kristanto et al. 2018). Untuk mempermudah dalam memetakan permasalahan pada Mitra, dapat dilihat pada Tabel 2.

TABEL 2

Permasalahan Mitra

\begin{tabular}{|c|c|c|c|}
\hline \multirow{2}{*}{ No } & \multirow{2}{*}{$\begin{array}{c}\text { Dimensi } \\
\text { Bisnis }\end{array}$} & \multicolumn{2}{|c|}{ Permasalahan } \\
\hline & & Mitra 1 & Mitra 2 \\
\hline 1 & $\begin{array}{l}\text { Aspek } \\
\text { Produksi }\end{array}$ & $\begin{array}{l}\text { - Peralatan } \\
\text { yang } \\
\text { digunakan } \\
\text { masih } \\
\text { sederhana } \\
\end{array}$ & $\begin{array}{l}\text { - Peralatan } \\
\text { yang } \\
\text { digunakan } \\
\text { masih } \\
\text { sederhana } \\
\end{array}$ \\
\hline 2 & $\begin{array}{l}\text { Aspek } \\
\text { Produk }\end{array}$ & $\begin{array}{l}\text { - Bentuk otak- } \\
\text { otak ikan } \\
\text { masih lonjong } \\
\text { panjang }\end{array}$ & $\begin{array}{ll}\text { - Varian } & \text { rasa } \\
\text { masih } & \text { ikan } \\
\text { tenggiri } & \end{array}$ \\
\hline
\end{tabular}




\begin{tabular}{|c|c|c|c|}
\hline & & $\begin{array}{ll}\text { - Varian } & \text { rasa } \\
\text { masih } & \text { ikan } \\
\text { tenggiri } & \end{array}$ & 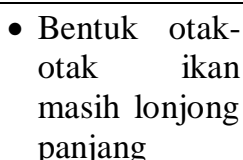 \\
\hline 3 & $\begin{array}{l}\text { Aspek } \\
\text { Pemasaran }\end{array}$ & $\begin{array}{l}\text { - } \text { Tidak ada } \\
\text { media } \\
\text { pemasaran } \\
\text { - Kurang } \\
\text { kegiatan } \\
\text { promosi }\end{array}$ & $\begin{array}{l}\text { - } \text { Tidak ada } \\
\text { media } \\
\text { pemasaran } \\
\text { - Kurang } \\
\text { kegiatan } \\
\text { promosi }\end{array}$ \\
\hline
\end{tabular}

\section{TARGET LUARAN}

Target luaran dari kegiatan pengabdian adalah membantu masyarakat dan Mitra dapat meningkatkan pendapatan dan mengembangkan keterampilan dalam pengolahan dan pembuatan produk otak-otak ikan. Target luaran lain yang dihasilkan dari kegiatan pengabdian adalah publikasi artikel ilmiah di jurnal pengabdian masyarakat (Ulfiyanti et al. 2018).

\section{Metode PELAKSANAAN}

Solusi yang ditawarkan merupakan target keberhasilan yang dicapai antara Tim Pengabdian dengan Mitra. Adapun target keberhasilan yang dicapai yaitu :

- Dapat mengurangi biaya pengeluaran dari pembuatan produksi otak-otak ikan.

- Dapat mendesain bentuk kemasan yang lebih sederhana sehingga mempunyai nilai jual tinggi.

- Dapat memasarkan produk otak-otak ikan dengan pemasaran online melalui media internet.

Berikut tahapan dari pelaksanaan pengabdian yang dilakukan, dapat dilihat pada Gambar 6.

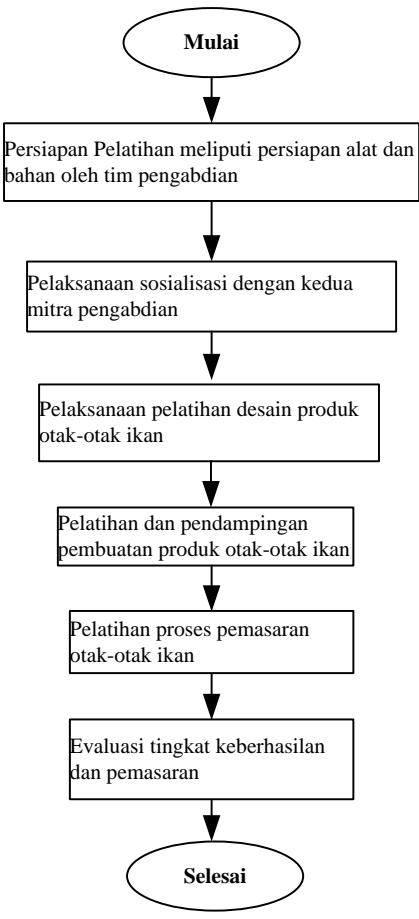

Gambar 6. Metode pelaksanaan

\section{HASIL DAN PEMBAHASAN}

Hasil yang dicapai dari kegiatan pengabdian sesuai solusi yang ditawarkan yaitu :

\section{A. Pendampingan Kegiatan Pengabdian}

Tim pengabdian melakukan persiapan dalam pendampingan ke Mitra yaitu cara mengoperasikan laman web. Dimulai dari menambah produk otak-otak ikan, cara mengganti produk, cara melakukan pembayaran, cara konfirmasi pembayaran, dan cara memasarkan produk ke media internet.

Dalam waktu seketika, Mitra dapat mengoperasikan dan memasarkan ke media internet. Dikarenakan Mitra melek internet, dengan mudah Mitra beradaptasi dengan internet. Pendampingan kegiatan pengabdian dapat dilihat pada Gambar 7.

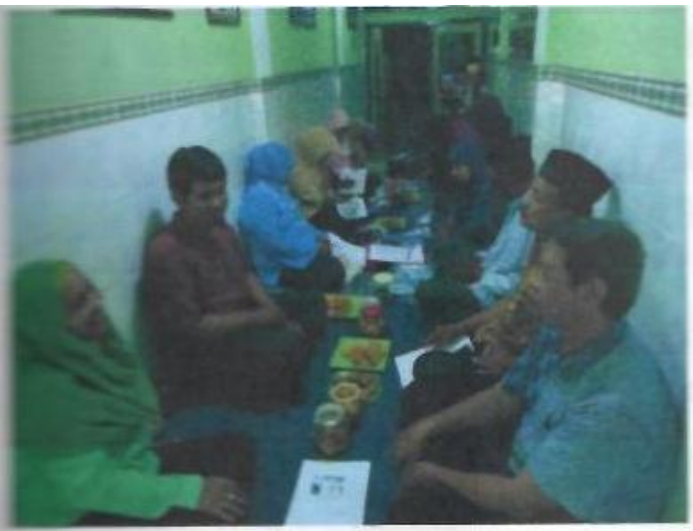

Gambar 7. Pendampingan kegiatan pengabdian otak-otak ikan 


\section{B. Penyuluhan Pembuatan dan Pemasaran Otak-Otak Ikan}

Setelah melakukan kegiatan pendampingan, selanjutnya tim pengabdian melakukan penyuluhan pembuatan otak-otak ikan. Tahap pertama, melakukan persiapan bahan baku dari otak-otak ikan, cara pembuatan otak-otak ikan, cara memasak otak-otak ikan dan menyajikan otak-otak ikan.

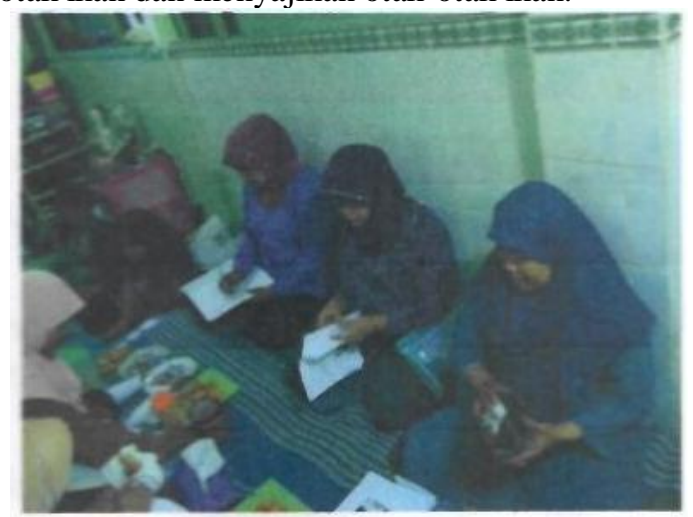

Gambar 8. Penyuluhan pembuatan otak-otak ikan

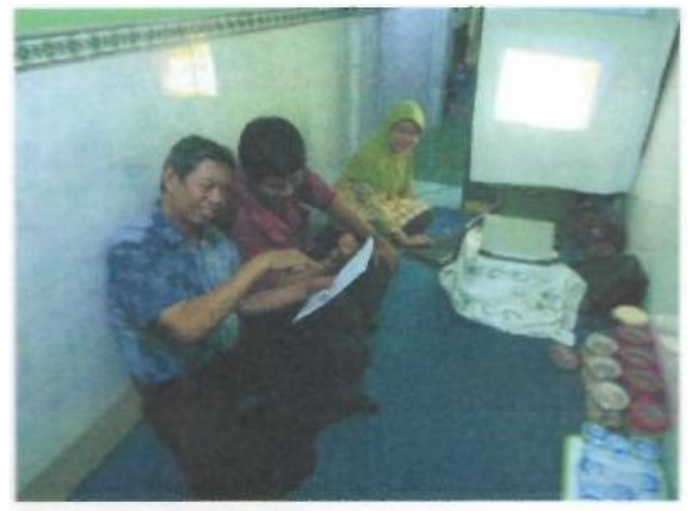

Gambar 9. Pendampingan pemasaran otak-otak ikan

\section{Rencana Tahapan Selanjutnya}

Setelah kegiatan pendampingan, pelatihan, dan pemasaran otak-otak ikan, tahapan selanjutnya adalah :

- Melakukan pantauan hasil dari kegiatan oleh Mitra PKM.

- Melakukan evaluasi kegiatan pengabdian.

- Melakukan pendampingan berkelanjutan ke Mitra PKM apabila dibutuhkan.

\section{SIMPULAN}

Berdasarkan hasil dari pendampingan dan, pelatihan kepada Mitra PKM, disimpulkan yaitu :

- Tingkat keikutsertaan dari Mitra IbM memberikan dampak positif.

- Meningkatkan omset pendapatan dari penjualan otakotak ikan.

\section{Daftar Pustaka}

[1] Kristanto, Titus, Eka Cahya Muliawati, Rachman Arief, and Syaiful Hidayat. 2018. "Peningkatan Kualitas Produksi UKM Percetakan Di Karangpilang Surabaya Dan Krian Sidoarjo." AKSIOLOGIYA: Jurnal Pengabdian Kepada Masyarakat 2(1): 33-38.

[2] Ulfiyanti, Yuni, M. Shofiul Amin, Mirza Ghulam R, and Sari Wiji Utami. 2018. "Pelatihan Penyusunan Rencana Anggaran Biaya Infrastruktur Desa Bagi Perangkat Desa Di Desa Karangbendo Kecamatan Rogojampi." J-Dinamika: : Jurnal Pengabdian Masyarakat 3(1): 19-24. 